\title{
Repeated Exposure to One Song Leads to a Rapid and Persistent Decline in an Immediate Early Gene's Response to That Song in Zebra Finch Telencephalon
}

\author{
Claudio Mello, ${ }^{1}$ Fernando Nottebohm, ${ }^{1}$ and David Clayton ${ }^{2}$ \\ 'Rockefeller University, Laboratory of Animal Behavior, New York, New York 10021 and ${ }^{2}$ The Beckman Institute, \\ Neuroscience Program and Department of Cell and Structural Biology, University of Illinois, Urbana, Illinois 61801
}

\begin{abstract}
Conspecific song induces a prompt increase in the expression of the zenk gene in the caudo-medial neostriatum (NCM), a part of the auditory telencephalon of songbirds. To test the hypothesis that zenk gene induction in NCM is related to the acquisition of new song-related memories, we presented adult male zebra finches with repeated playbacks of one song. In reponse, zenk mRNA levels in NCM increased for the first $\mathbf{3 0} \mathrm{min}$, but then declined back to baseline levels despite continued stimulation with the same song. When a novel song was then introduced, however, a full zenk response was triggered once again. Even when a full day had passed between the last exposure to a song and the testing period, the song that had been rendered "familiar" by repetition caused no zenk response, whereas a novel song caused a full response. Quantitative analysis indicates that individual cells in NCM must have undergone a selective loss in their zenk responsiveness to the repeated song, while still maintaining their ability to respond to the novel song. These results support the hypothesis that the induction of zenk is related to the formation of long-term memories. Analysis of the stimulusspecific modulation of zenk responses, coupled with appropriate behavioral assays, should provide insight into neural mechanisms responsible for the discrimination and storage of complex perceptual Information.
\end{abstract}

[Key words: zenk, immediate early gene, songbird, zebra finch, neostriatum, NCM, vocal communication, auditory discrimination, song, consolidation]

Oscine songbirds sing to defend their territories and attract mates. In both cases, it is important that the receiver of the song signal discriminate among individual senders (Brooks and Falls, 1975; Krebs, 1976, 1977; Peters et al., 1980; Searcy et al., 1981 a,b; Catchpole, 1982; Kroodsma and Byers, 1991; Wiley et al., 1991). A potential component of the neural circuitry responsible for learned song discrimination was recently revealed by studies using molecular probes to analyze the expression of "immediate early genes" (IEGs) in the songbird brain (Mello et al., 1992). Playback of taped conspecific song for as little as $10 \mathrm{~min}$

Received Feb. 20, 1995; revised May 9, 1995; accepted May 24, 1995.

We thank S. Volman, R. Stripling, J. George, G. Robinson, D. Vicario, and E. Jarvis for constructive conversations and advice on the manuscript. This work was supported by grants from the NIH and the Whitehall Foundation.

Correspondence should be addressed to Dr. David F. Clayton, Beckman Instititute/NPA, 405 North Mathews Avenue, Urbana, IL 61801.

Copyright (C) 1995 Society for Neuroscience 0270-6474/95/156919-07\$05.00/0 was sufficient to induce an increase in mRNAs for two IEGs in the caudo-medial neostriatum (NCM) of zebra finches and canaries (Mello and Clayton, 1994; Nastiuk et al., 1994). NCM represents a relatively uncharacterized area of the telencephalon that receives input from primary auditory centers, and is reciprocally connected with at least two other areas of the telencephalon (Mello and Clayton, 1994).

The functional significance of this genomic response to song is not known, but two observations suggest it may be linked to the experience-dependent modification of neural circuits engaged in song recognition and discrimination. First is the fact that conspecific song caused a greater response than did the song of a different species, whereas simpler auditory stimuli such as tone-bursts did not cause any detectable induction (Mello et al., 1992). Thus the genomic response in NCM may be somehow coupled to the presentation of perceptually "significant" stimuli, as opposed to simple auditory activation. Second is the nature of the protein products synthesized as a result. Two responsive genes have now been identified: zenk (Mello et al., 1992) and $c$-jun (Nastiuk et al., 1994). Both encode proteins that regulate the transcription of yet other "downstream" or "late" genes (Milbrandt, 1987; Lemaire et al., 1988; Sukhatme et al., 1988; Christy and Nathans, 1989). Transient induction of these and other IEGs following neuronal stimulation has been widely discussed as a mechanism specifically necessary for the consolidation of synaptic changes underlying long-term memory formation (e.g., Goelet et al., 1986; Cole et al., 1989; Wisden et al., 1990; Stevens, 1994). Interference with IEG induction has been shown to block long-term (but not short-term) facilitation in cultured Aplysia neurons (Alberini et al., 1994). Genetic mutations that disrupt the signal transduction pathways responsible for IEG induction also disrupt long-term memory formation in mice (Bourtchuladze et al., 1994) and fruit flies (Yin et al., 1994).

These precedents suggest the hypothesis that zenk gene activation in songbird NCM is causally related to the formation of long-term memories associated with specific song stimuli. This hypothesis predicts that the degree of zenk activation in NCM should vary depending upon the familiarity of a song stimulus and the context of its presentation. In other words, stimuli that trigger long-term memory formation (e.g., novel stimuli, or familiar stimuli in novel contexts) should cause a greater induction of zenk than should already-familiar stimuli. Once a novel stimulus has been rendered familiar by repetition, presentation of this stimulus in the same context should no longer induce a zenk response. As a test of this, we presented individual songs re- 


\begin{tabular}{|c|c|c|c|}
\hline Train/lest & Labeled cells & Total cells & \% Labeled cells \\
\hline \multirow[t]{2}{*}{$0 / 0$} & 7 & 128 & 5.47 \\
\hline & 11 & 133 & 8.27 \\
\hline \multirow[t]{2}{*}{$0 / \mathrm{S} 1$} & 54 & 109 & 49.54 \\
\hline & 70 & 142 & 49.30 \\
\hline \multirow[t]{2}{*}{$0 / \mathrm{S} 2$} & 46 & 108 & 42.59 \\
\hline & 71 & 130 & 54.61 \\
\hline \multirow[t]{2}{*}{$\mathrm{S} 1 / \mathrm{S} 1$} & 6 & 99 & 6.06 \\
\hline & 9 & 111 & 8.11 \\
\hline \multirow[t]{2}{*}{$\mathrm{S} 1 / \mathrm{S} 2$} & 60 & 127 & 47.24 \\
\hline & 52 & 113 & 46.02 \\
\hline
\end{tabular}

peatedly to adult male zebra finches, and analyzed the the zenk response in NCM using in situ hybridization assays.

An abstract of these data has been published (Clayton and Mello, 1993).

\section{Materials and Methods}

Song presentation. Zebra finches were raised in closed colonies maintained at the Rockefeller University Field Research Center (Millbrook, $\mathrm{NY}$ ) or at the Beckman Institute of the University of Illinois (Urbana, IL). In order to normalize the birds' history of exposure to auditory stimuli, all birds used in each experiment were raised in the same aviary. Individual adult males of similar ages were initially placed in acoustic isolation for $1 \mathrm{~d}$. They were then presented with playbacks of tape-recorded conspecific songs, as previously described (Mello et al., 1992; Mello and Clayton, 1994). Each minute of the song tapes contained $15 \mathrm{sec}$ of one song, followed by $45 \mathrm{sec}$ of silenec. The total duration and the exact schedules of the song playbacks are detailed in the results section. For the experiment in Figure 5, after the first day of acoustic isolation, birds were trained on one song over a five day period with a total of $3 \mathrm{hr}$ of playback each day, in separate hour-long sessions (matched controls heard only silence). A day after the last training session, the birds were tested as described in Figure 5. Each bird was maintained in its cage within the song stimulation booth throughout the week-long experiment. All animal experimentation procedures were conducted in accordance with the policies of the Society for Neuroscience.

In situ hybridization and densitometry. Animals were sacrificed by decapitation at the end of playbacks and brains immediately dissected from the skulls and frozen in TissueTek. In situ hybridization of frozen parasagittal brain sections $(10 \mu \mathrm{m})$ was performed essentially as described before (Clayton et al., 1988) with modifications (Mello and Clayton, 1995), using a ${ }^{35} \mathrm{~S}$-labeled zenk antisense riboprobe followed by $\mathrm{x}$-ray film autoradiography. Regional densitometry over the caudomedial neostriatum (NCM) was performed using NIH IMAGE software, as described (Mello and Clayton, 1994). NCM boundaries and the criteria for distinguishing NCM from Field $\mathrm{L}$ and caudal HV have been previously discussed in detail (Mello and Clayton, 1994).

Cellular analysis. Hybridized sections, from two birds in each of the first five groups in Figure $3 b$, were coated with autoradiographic emulsion and exposed for 6-8 weeks. After developing and Nissl staining (Mello, et al., 1992), labeled cells with neuronal morphology (large, with large pale-staining nucleus, distinct nucleolus, and abundant Nisslsubstance, see Fig. 4) were counted in five randomly chosen fields of $90 \times 120 \mu \mathrm{m}$ within NCM, and the sum of the counts for each bird is presented in Table 1 . A cell was counted as labeled if the overlying autoradiographic grain density was at least five times greater than the background density (Ineasured over an equivalent area outside the boundaries of the tissue).

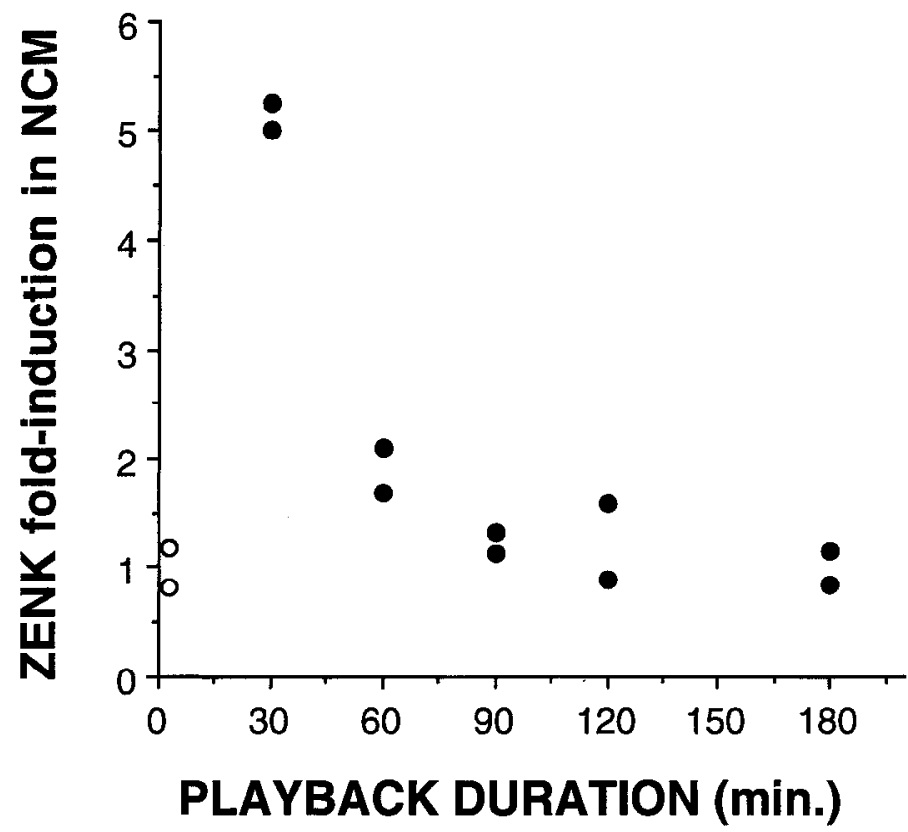

Figure 1. Induced zenk mRNA levels in NCM eventually decline during continuous song stimulation. Each dot represents zenk mRNA abundance in NCM in one adult male zebra finch (assayed by in situ hybridization) after continuous song playback of the duration indicated (xaxis), normalized to matched controls that heard silence (open circles).

\section{Results}

The first experiment was to present adult male zebra finches with continued playbacks of a single tape-recorded song (15 sec of song every minute), and at various intervals measure zenk mRNA levels in NCM by in situ hybridization. We previously showed that accumulation of zenk mRNA in NCM following 10 min of song stimulation is transient, reaching a peak at 30 min and returning back to unstimulated levels after $60 \mathrm{~min}$ (counting from stimulus onset) (Mello and Clayton, 1994). We also showed that zenk mRNA levels increase in NCM in direct proportion to playback duration, for durations of 10-30 min (Mello and Clayton, 1994). Figure 1 shows, however, that when song presentation continued for longer than $30 \mathrm{~min}$, zenk mRNA levels gradually subsided to levels undistinguishable from unstimulated controls despite the continued presentation of song playbacks.

In the sccond expcriment, we asked whether a new song would reactivate zenk expression, at a time when the zenk response to the first song had ceased, as in Figure 1. Male zebra finches were first exposed to one of two conspecific song stimuli (Fig. 2, S1 or S2) for a $2.5 \mathrm{hr}$ "training" period. Then, for the next $30 \mathrm{~min}$ (the "testing" period), they were exposed to either the same song or the other song, and zenk levels in NCM were analyzed (Fig. 3). Birds that heard the same song during both periods (Fig. 3, groups S1/S1 or S2/S2) had levels of zenk mRNA in NCM that were significantly lower than levels in controls hearing either song for the first time during the testing period $(0 / \mathrm{S} 1$ or $0 / \mathrm{S} 2)$ and were equivalent to levels in unstimulated controls $(0 / 0)$, consistent with the result of the first experiment (Fig. 1). In marked contrast, birds that heard a different song during the testing period (Fig. 3, S1/S2, or S2/S1) had levels of zenk mRNA in NCM that were significantly higher than levels in birds that heard the same song during both periods (S1/ $\mathrm{S} 1$ or $\mathrm{S} 2 / \mathrm{S} 2$ ), and were comparable to levels seen in controls 

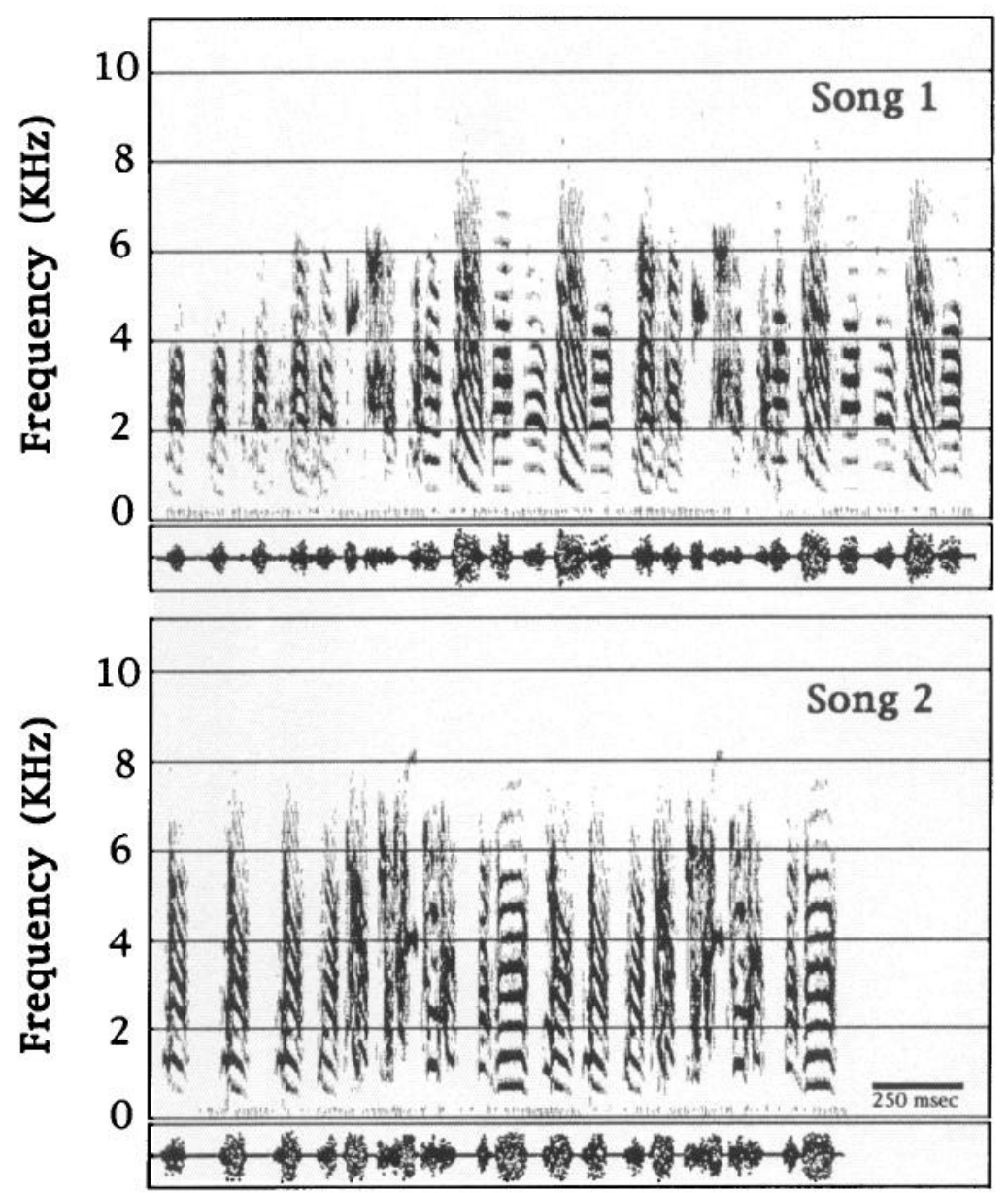

Figure 2. Sonograms (plots of frequency vs time) representing the two songs used in Figures 3 and 4. Depicted are the introductory notes and two repetitions of the motifs of Song 1 (S1) and Song 2 (S2). The corresponding plot of amplitude versus time is aligned underneath each sonogram. hearing either song for the first time during the testing period $(0 / \mathrm{S} 1$ or $0 / \mathrm{S} 2)$. Thus, although the population of cells in NCM had ceased their zenk response to the repeated song, they responded fully to a new song. The statistical significance of these conclusions was confirmed as described at the end of this section.

To determine the number and types of cells that show zenk expression, in situ hybridized brain sections from the previous experiment (Fig. 3) were subjected to emulsion autoradiography and examined under the light microscope. Consistent with our previous findings (Mello et al., 1992; Mello and Clayton, 1994, 1995), labeled cells typically had a neuronal morpology and displayed an "all or none" zenk response. Typical examples of labeled neurons in NCM can be seen in Figure 4. Figure $4 B$ shows two isolated neuronal cells, one of which is positive for $z e n k$, and Figure $4 A$ illustrates the fact that individual labeled neurons can be identified and counted even when they occur in cell clusters. By counting the fraction of cells in NCM that were labeled with the zenk probe (Table 1), we observed that in the first $30 \mathrm{~min}$ presentation, either song elicited a zenk response in roughly half the cells with neuronal morphology in NCM (groups 0/S1 and 0/S2). In birds exposed to continued repetitions of the same song (S1/S1), the number of labeled cells then dropped to control levels $(0 / 0)$. Yet presentation of a new song activated zenk expression once again in roughly half the NCM neurons (S1/S2).

The third experiment was designed to assess whether the apparent change in the response to the repeated song (Fig. 3) can persist for longer times after the initial training period. In order to maximize our chances of seeing a long-term retention of the change observed in the zenk response, we repeated the training sessions across $5 \mathrm{~d}$, and then waited one more day after training before the final $30 \mathrm{~min}$ testing period. As presented in Figure 5, birds showed no significant zenk response to the song they heard during the training period, when tested a day after the last training exposure (S1/S1, compare with control groups $0 / 0$ and $\mathrm{S} 1 /$ $0)$. In contrast, when such birds were tested with a song different from the training song (S1/S2), zenk was induced to the same degree as in naive controls hearing either song for the first time $(0 / \mathrm{S} 1,0 / \mathrm{S} 2)$. We have not examined whether training periods of less than $5 \mathrm{~d}$ would be sufficient to achieve a persisting change in response selectivity, or whether an acquired change can persist for even longer than a day.

To evaluate the statistical significance of the results presented in Figures 3 and 5, we used the Mann-Whitney $U$ test (criterion of $P<0.05$, two-tailed probabilities). In Figure 3, significant differences were seen when group S1/S1 $(n=4)$ was compared with groups $0 / \mathrm{S} 1(n=4, U=0, P=0.028)$ and $\mathrm{S} 1 / \mathrm{S} 2(n=$ $4, U=0, P=0.028$ ). No significant differences were seen when group $\mathrm{S} 1 / \mathrm{S} 1(n=4)$ was compared with group $0 / 0(n=4, U$ $=3, P=0.2$ ) or when group $\mathrm{S} 1 / \mathrm{S} 2$ was compared with groups $0 / \mathrm{S} 1(n=4, U=3, P=0.2)$ or $0 / \mathrm{S} 2(n=4, U=5, P=$ 0.49 ). Groups $S 1 / \mathrm{S} 1$ and $S 2 / S 2$ were then combined into a "repeated song" group $(n=6)$, groups $0 / \mathrm{S} 1$ and $0 / \mathrm{S} 2$ into a "novel song after silence" group $(n=8)$ and groups $\mathrm{S} 1 / \mathrm{S} 2$ and $\mathrm{S} 2 / \mathrm{S} 1$ into a "novel song after repeated song" group $(n=6)$. The 

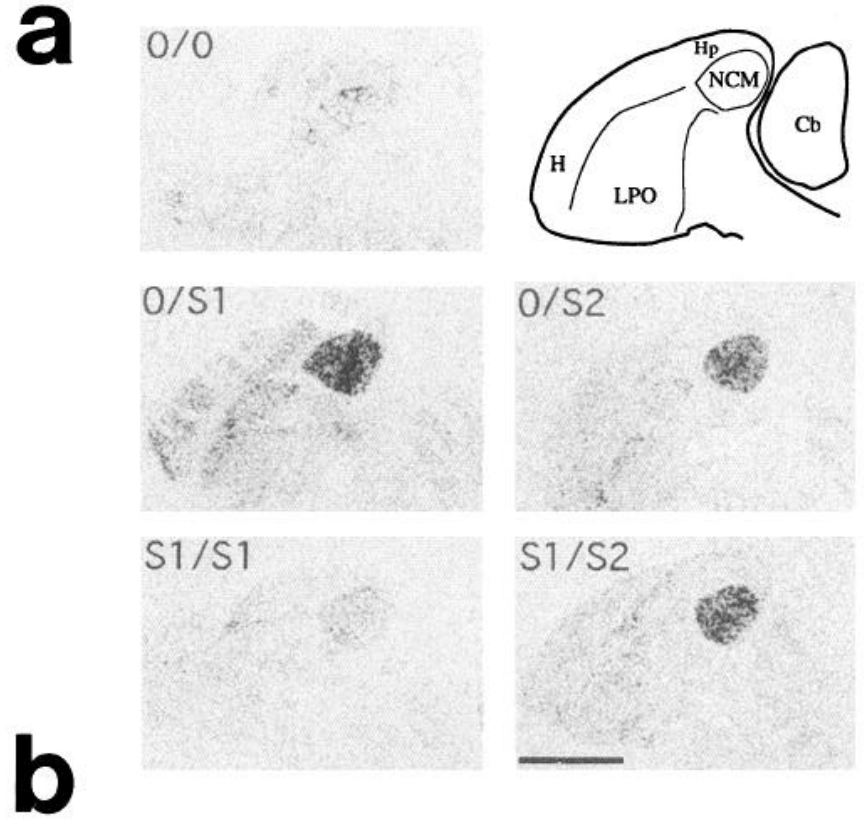

Figure 3. zenk is reinduced by exposure to a new song. Animals were presented with a repeated song stimulus (as in Fig. 1) for a $2.5 \mathrm{hr}$ "training" period, immediately followed by a second "test" stimulus for another $30 \mathrm{~min}$ (zenk mRNA levels in NCM were analyzed as in Fig. 1). The combined training-test protocol for each experimental group is indicated (first stimulus/second stimulus). $S 1$ and $S 2$ represent the specific songs of two different individuals from another aviary (Fig. 2 ), and 0 represents silence. $A$, Representative in situ hybridization autoradiograms of parasagittal brain sections (200 $\mu \mathrm{m}$ from midline). The diagram on the upper right indicates the visible structures: $\mathrm{Cb}$, cerebellum; $H$, hyperstriatum; $H p$, hippocampus; $L P O$, lobus parolfactorius; NCM, caudo-medial neostriatum. Scale bar, $3 \mathrm{~mm}$. $B$, Quantitative analysis of zenk hybridization signal in NCM. Each dot represents zenk mRNA abundance in NCM in one animal, and the bars represent means for each experimental group.

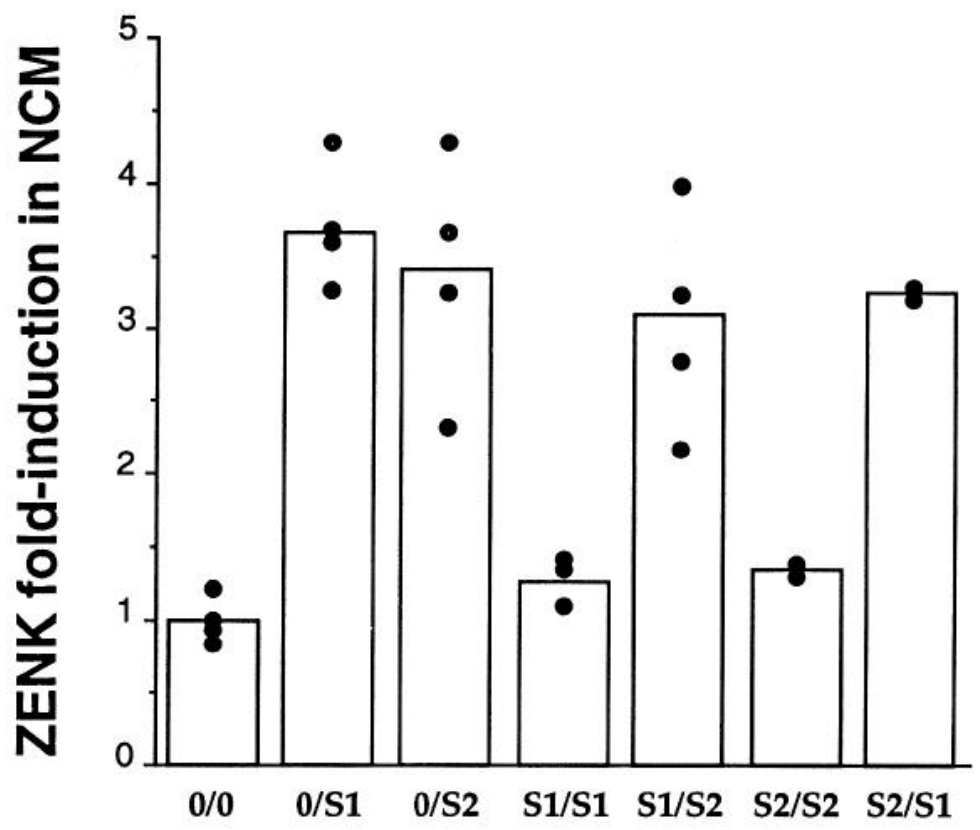

combined "repeated song" group was significantly different from both the "novel song after silence" group $(U=0, P<$ $0.001)$ and the "novel song after repeated song" group $(U=0$, $P=0.001)$. In contrast, no significant difference was seen between the "novel song after silence" and the "novel song after repeated song" groups ( $U=14, P=0.23)$. In Figure 5, no significant differences were seen when group $\mathrm{S} 1 / \mathrm{S} 1(n=5)$ was compared with groups $0 / 0(n=4, U=9, P=0.9)$ or $\mathrm{S} 1 / 0$ ( $n$ $=4, U=7, P=0.56)$. In contrast, group S1/S2 $(n=5)$ was significantly different from group S1/S1 $(n=5, U=0, P=$ $0.004)$ but not from group $0 / \mathrm{S} 1(n=4, U=10, P=0.99)$.

\section{Discussion}

The idea that new gene expression is necessary for memory formation has been supported for about 30 years (Agranoff et al., 1966; Barondes and Cohen, 1968; Bateson et al., 1972;
Flood et al., 1977; Gibbs and Ng, 1977; Flexner et al., 1983; Davis and Squire, 1984; Goelet et al., 1986; Montarolo et al., 1986), but the mechanistic significance of this for brain function is not well understood. The ability of tape-recorded natural birdsong to induce zenk gene expression in the telencephalon (Mello et al., 1992; Mello and Clayton, 1994) provides a specific experimental paradigm for evaluating the relationship between gene expression, neural circuit activation, and behavioral function. In this report we have described experiments to test whether the zenk gene response to song is a fixed and invariant correlate of sensory stimulation, or whether it can be modulated by the experiential context in which the stimulation occurs.

We show here, first, that the increase in zenk expression is transient, even in the face of continuous song stimulation (Fig. 1). On its own, the initial rapid decline in zenk mRNA levels might appear to suggest the emergence of a nonspecific "re- 

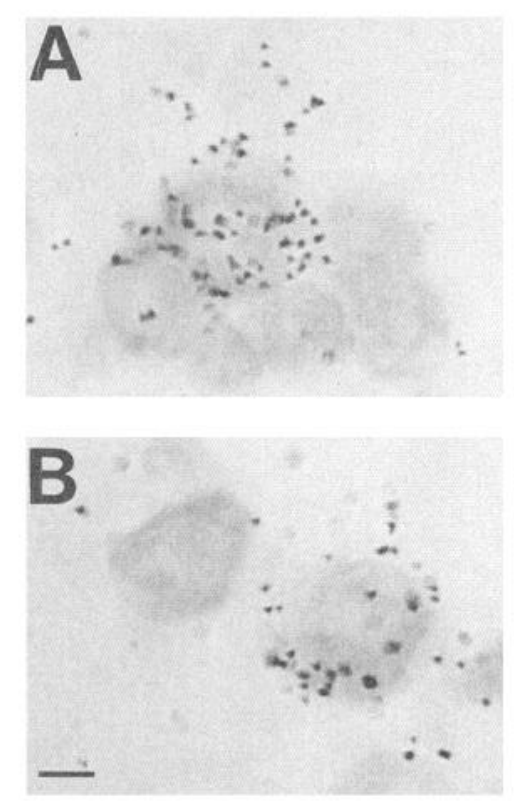

Figure 4. Detection of individual cells expressing zenk in NCM after song presentation. Brain sections (from a bird in group O/S1, Fig. 3) were hybridized with zenk riboprobe, exposed to autoradiographic emulsion and counterstained with cresyl violet; the optical focus of both panels is on the autoradiographic grains. $A$, A neuronal cluster containing six cells, one of which expresses zenk; $B$, two isolated NCM neurons, one of which is positive for zenk. Scale bar, $6 \mu \mathrm{m}$.

fractory period" for gene induction, as has been observed in some other experimental systems after a wave of IEG expression (Morgan et al., 1987; Morgan and Curran, 1991). However, we also observed that zenk gene expression can be reactivated by presentation of a new song (Fig. 3). Even when the bird had rested for a day after its last exposure to song stimuli, zenk induction in NCM was elicited only by a novel song and not by a song previously made familiar (Fig. 5). Thus the zenk gene in NCM was not merely made refractory; rather, its stimulus-response profile was changed in a highly specific fashion. It is important to note that this does not necessarily prove that no refractory period for zenk induction occurred at some other time in these experiments, since we did not test for the ability of novel stimuli to sustain zenk expression during the initial phase of mRNA decline (e.g., 45-120 min, Fig. 1). The cellular mechanisms that contribute to the initial decline in zenk may not be the same as the mechanisms that underlie the subsequent inability of a familiar song to reinduce zenk. Additional insights into the underlying cellular mechanisms might be gained from direct measurements of the rate of zenk gene transcription, to complement the "steady state" mRNA measurements here which reflect the sum of both synthetic and degradative cellular processes.

These results raise immediate questions about the pattern of electrophysiological activity induced in NCM by song presentation, and how that may be related to the observed changes in genomic activity. Electrophysiological studies undertaken as a result of these experiments have indeed given indication that song presentation elicits an excitatory response in NCM, which declines as a particular song stimulus is presented again and again (Stripling et al., 1994; Chew et al., 1995). The intracellular mechanisms responsible for IEG induction are not yet well defined, but a song-specific decline in neuronal firing rate could

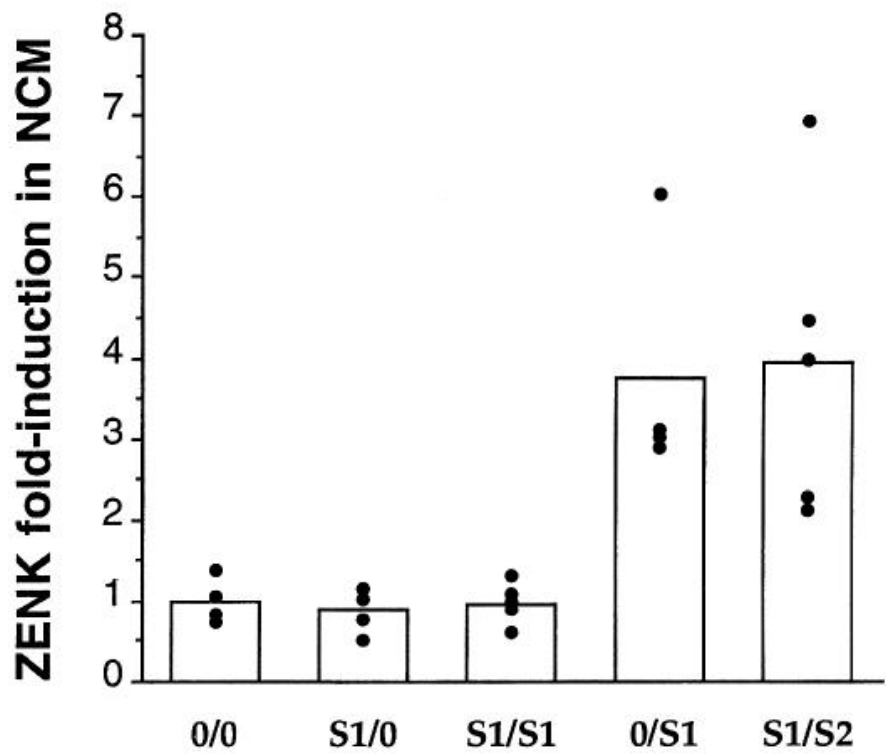

Figure 5. Song-selective extinction of zenk induction can be maintained for at least one day. Experiment is similar to Figure 3, except that the training period spanned $5 \mathrm{~d}$, and the birds were then tested on the 6th day.

underlie the inability of familiar songs to reinduce the zenk response. Such an electrophysiological change might, in turn, require expression of IEG proteins for its long-term consolidation.

In the context of the neural circuitry, a stimulus-specific change in electrophysiological and/or genomic responsiveness might come about in several ways. (1) Arousal or attention may vary with stimulus familiarity, and these organismal variables could impinge upon NCM via neuromodulatory systems that project diffusely throughout the brain (Kaczmarek and Levitan, 1987; Lopez and Brown, 1992). Drawing a parallel with the natural situation, novel songs might signify the presence of unknown or intruder males and thus be more arousing, whereas familiar songs would represent neighbors recognized as unthreatening. A possibly similar situation has recently been described in rats, where IEG responses to environmental cues were conditionally activated by previous pairing with fear-inducing stimuli (Beck and Fibiger, 1995). (2) The change in NCM could reflect a stimulus-specific decline in the firing of lower auditory centers that provide input to NCM. This seems somewhat unlikely, however, since cells in the known auditory areas that project to NCM (Field L and nucleus ovoidalis, Mello, 1993; Mello and Clayton, 1994) appear to be tuned to fundamental acoustic characteristics common to all songs (such as frequency) and not to specific songs (Müller and Leppelsack, 1985; Müller and Scheich, 1985). (3) There could be an increase in inhibitory inputs, perhaps mediated by the reciprocal connections between NCM and other sites of zenk induction in the forebrain (Mello, 1993; Mello and Clayton, 1994). (4) It is also conceivable that individual neurons are capable of changing their responses to specific patterns of presynaptic stimulation autonomously, without affecting their responses to other patterns-if, for example, the stimuli impinge upon different anatomical compartments in the dendritic arbor (e.g., Tank et al., 1988; Midtgaard, 1994).

Our densitometric zenk measurements reflect the average level of zenk gene activity for all cells within NCM. Therefore, we do not know for certain whether the neurons that initially showed the zenk response to $\mathrm{S} 1$, and then lost that response, 
were necessarily the same neurons that later showed the zenk response to $\mathrm{S} 2$. If, however, there were separate, nonoverlapping populations of cells tuned to each song, the data in Table 1 would have to be taken as indication that essentially all the neurons in NCM became "habituated" by the presentation of just two songs; the bird would then not have any NCM neurons left to give a zenk response to still other songs, which seems unlikely. A more probable interpretation, supported also by electrophysiological studies (Stripling et al., 1994; Chew et al., 1995), is that the population of cells that responded to S1 includes cells that also responded to $\mathrm{S} 2$; these cells then selectively extinguished their zenk response to one song but not the other. We find this possibility, and its significance, particularly intriguing in two ways. First, it suggests that the same neuron may be involved in the acquisition of multiple and/or successive song memories. Second, it implies that cells (or circuits of cells) are capable of modulating their IEG responses to specific stimuli. If IEG responses are indeed necessary for memory consolidation (Goelet et al., 1986; Alberini et al., 1994), then modulation of IEG responses might allow the consolidation of only selcetcd memories from among those initially represented in short-term memory. One testable prediction of this hypothesis is that a novel stimulus presented when zenk activity is already high (e.g., induced by a prior stimulus) might be consolidated more quickly or effectively.

Conspecific song is more effective than heterospecific song in increasing zenk expression in NCM (Mello et al., 1992). When this result was first reported it seemed possible that the differences in the effectiveness of these two stimuli could be directly related to their familiarity: birds would be expected to be more familiar with the song of their own species, and perhaps that accounted for the greater activation of zenk. Our present results weaken this interpretation, because we show that as an individual conspecific song is made familiar by repeated presentation, the zenk response to that song decreases and eventually disappears. The degrec of zenk induction thus appears to be inversely correlated with stimulus/context familiarity, although we have not yet performed any behavioral tests of the animal's ability to discriminate between the stimuli. The greater effectiveness of conspecific compared to heterospecific song in inducing zenk expression in NCM (Mello et al., 1992) may derive from the special acoustic properties of conspecific song and the way in which they engage the responsiveness of NCM neurons, when presented as stimuli in a novel context. This interpretation does not exclude the possibility that the preference for conspecific song is acquired as a result of earlier experience, similar perhaps to the acquisition of preference for the bird's own song by neurons of the song control nuclei during song juvenile song learning (Volman, 1993).

Adult songbirds of both sexes must constantly perceive-and if necessary discriminate and respond to-the songs they hear. Song activation of the zenk gene in adult birds may highlight circuitry that analyzes song stimuli for their novelty, individual identities and behavioral significance. A molecular approach to the study of song discrimination promises to yield rich insights into the mechanisms for integrating single neurons into the neural systems that underlie perception and vocal communication.

\section{References}

Agranoff B, Davis R, Brink J (1966) Chemical studies on memory formation in goldfish. Brain Res 1:303 309.

Alberini CM, Ghirardi M, Metz R, Kandel ER (1994) C/EBP is an immediate-early gene required for the consolidation of long-term facilitation in Aplysia. Cell 76:1099-1114.

Barondes S, Cohen H (1968) Effects of acetoxycycloheximide on learning and memory of a light-dark discrimination. Nature 218:271273.

Bateson P, Horn G, Rose S (1972) Effects of early experience on regional incorporation of precursors into RNA and protein in the chick brain. Brain Res 39:449-465.

Beck C, Fibiger H (1995) Conditioned fear-induced changes in behavior and in the expression of the immediate early gene c-fos: with and without diazepam pretreatment. J Neurosci 15:709-720.

Bourtchuladze R, Frenguelli B, Blendy J, Cioffi D, Schutz G, Silva A (1994) Deficient long-term memory in mice with a targeted mutation of the cAMP-responsive element-binding protein. Cell 79:59-68.

Brooks RJ, Falls JB (1975) Individual recognition by song in whitethroated sparrows. 1. Discrimination of songs of neighbors and strangers. Can J Zool 53:879-888.

Catchpole CK (1982) (Kroodsma DE, Miller EH, ed), pp 297-319. New York: Academic.

Chew S, Mello C, Nottebohm F, Jarvis E, Vicario D (1995) Decrements in auditory responses to a repeated conspecific song are long-lasting and require two periods of protein synthesis in the songbird forebrain. Proc Natl Acad Sci USA 92:3406-3410.

Christy B, Nathans D (1989) DNA binding site of the growth factorinducible protein Zif268. Proc Natl Acad Sci USA 86:8737-8741.

Clayton DF, Mello CV (1993) Experience-dependent modification of ZENK gene induction following song presentation in adult zcbra finches. Soc Neurosci Abstr 19:807.

Clayton DF, Huecas ME, Sinclair-Thompson EY, Nastiuk KL, Nottebohm F (1988) Probes for rare mRNAs reveal distributed cell subsets in canary brain. Neuron 1:249-261.

Cole AJ, Saffen DW, Baraban JM, Worley PF (1989) Rapid increase of an immediate early gene messenger RNA in hippocampal neurons by synaptic NMDA receptor activation. Nature 340:474-476.

Davis HP, Squire LR (1984) Protein synthesis and memory: a review. Psychol Bull 96:518-559.

Flexner J, Flexner L, Stellar E (1983) Memory in mice as affected by intracerebral puromycin. Science 141:57-59.

Flood J, Bennett E, Orme A, Jarvik M (1977) Protein synthesis dependent gradient of ECS retrograde amnesia. Behav Biol 21:307328.

Gibbs M, Ng K (1977) Psychobiology of memory: towards a model of memory formation. Biobehav Rev 1:113-136.

Goelet P, Castelucci V, Schacher S, Kandel E (1986) The long and the short of long-term memory-a molecular framework. Nature 332: 419-422.

Kaczmarek L, Levitan I (1987) Neuromodulation: the biochemical control of neuronal excitability. Oxford: Oxford UP.

Krebs JR (1976) Habituation and song repertoires in great tit. Behav Ecol Sociobiol 1:215-227.

Krebs JR (1977) Significance of song repertoires-the beau geste hypothesis. Anim Behav 25:475-478.

Kroodsma DE, Byers BE (1991) The function(s) of bird song. Am Zool 31:318-328.

Lemaire P, Revelant O, Bravo R, Charnay P (1988) Two mouse genes encoding potential transcription factors with identical DNA-binding domains are activated by growth factors in cultured cells. Proc Natl Acad Sci USA 85:4691-4695.

Lopez H, Brown A (1992) Neuromodulation. Curr Opinion Neurol $2: 317-322$

Mello CV (1993) Doctoral thesis. The Rockefeller University

Mello CV, Clayton DF (1994) Song-induced ZENK gene expression in auditory pathways of songbird brain and its relation to the song control system. J Neurosci 14:6652-6666.

Mello CV, Clayton DF (1995) Differential induction of the ZENK gene within the avian forebrain and song control circuit after metrazoleinduced depolarization. J Neurobiol 26:145-161.

Mello CV, Vicario DS, Clayton DF (1992) Song presentation induces gene expression in the songbird forebrain. Proc Natl Acad Sci USA 89:6818-6822.

Midtgaard J (1994) Processing of information from different sources: spatial synaptic integration in the dendrites of vertebrate CNS neurons. Trends Neurosci 17:166-173.

Milbrandt J (1987) A nerve growth factor-induced gene encodes a possible transcriptional regulatory factor. Science 238:797-799. 
Montarolo PG, Goelet P, Castellucci VF, Morgan J, Kandel ER, Schacher $S$ (1986) A critical period for macromolecular synthesis in longterm heterosynaptic facilitation in Aplysia. Science 234:1249-1254.

Morgan J, Curran T (1991) Stimulus-transcription coupling in the nervous system: involvement of the inducible proto-oncogenes fos and jun. Annu Rev Neurosci 14:421-451.

Morgan JI, Cohen DR, Hempstead JL, Curran T (1987) Mapping patterns of c-fos expression in the central nervous system after seizure. Science 237:192-197.

Müller CM, Leppelsack H (1985) Feature extraction and tonotopic organization in the avian auditory forebrain. Exp Brain Res 59:587599.

Müller SC, Scheich HP (1985) Functional organization of the avian auditory field L-a comparative 2-deoxyglucose study. J Comp Physiol 156:1-12.

Nastiuk KL, Mello CV, George JM, Clayton DF (1994) Immediateearly gene responses in the avian song control system: cloning and expression analysis of the canary c-jun cDNA. Mol Brain Res 27: 299-309.

Peters SS, Searcy WA, Marler P (1980) Species song discrimination in choice experiments with territorial male swamp and song sparrows. Anim Behav 28:393-404.

Searcy WA, Marler P, Peters SS (1981a) Species song discrimination in adult female song and swamp sparrows. Anim Behav 29:997-1003.

Searcy WA, McArthur PD, Peters SS, Marler P (1981b) Response of male song and swamp sparrow to neighbor, stranger and self songs. Behav 77:152-163.
Stevens C (1994) CREB and memory consolidation. Neuron 13:769770 .

Stripling R, Volman S, Clayton D (1994) Electrophysiological responses to song presentation in caudomedial neostriatum of zebra finches: links to ZENK gene induction. Soc Neurosci Abstr 20:165.

Sukhatme VP, Cao X, Chang LC, Tsai-Morris CH, Stamenkovitch D, Ferreira PCP, Cohen DR, Edwards SA, Shows TB, Curran T, LeBeau MM, Adamson ED (1988) A zinc finger-encoding gene coregulated with c-fos during growth and differentiation, and after cellular depolarization. Ccll 53:37-43.

Tank D, Sugimori M, Connor J, Llinas R (1988) Spatially resolved calcium dynamics of mammalian Purkinje cells in cerebellar slices. Science 242:773-777.

Volman SF (1993) Development of neural selectivity for birdsong during vocal learning. J Neurosci 13:4737-4747.

Wiley R, Tatchwell B, Davis N (1991) Recognition of individual males' songs by female dunnocks: a mechanism increasing the number of copulatory partners and reproductive success. Ethology 88: $145-153$.

Wisden W, Errington ML, Williams S, Dunnett SB, Waters C, Hitchcock D, Evan G, Bliss TVP, Ilunt SP (1990) Differential expression of immediate early genes in the hippocampus and spinal cord. Neuron $4: 603-614$.

Yin J, Wallach J, Del Vecchio M, Wilder E, Zhou H, Quinn W, Tully $T$ (1994) Induction of a dominant negative CREB transgene specifically blocks long-term memory in Drosophila. Cell 79:49-58. 